\title{
UJI EFEKTIVITAS SALEP EKSTRAK HERBA PEGAGAN (Centella asiatica (L.) Urban) TERHADAP LUKA BEDAH PADA TIKUS
}

\author{
Ahmad Azrul Zuniarto1 ${ }^{*}$, Rizki Rahmah Fauzia ${ }^{2}$ \\ ${ }^{1,2}$ Sekolah Tinggi Farmasi YPIB Cirebon \\ *Korespondensi: Jl. Perjuangan Majasem Cirebon, Email: aazuniarto@gmail.com
}

\begin{abstract}
ABSTRAK
Latar Belakang: Pegagan (Centella asiatica (L.) Urban) telah diteliti mempunyai aktivitas penyembuhan luka yang baik pada luka bedah dengan menstimulasi sintesis kolagen, meningkatkan sekresi kolagen, merangsang proliferasi fibroblast, aktivitas antibakteri dan antioksidan.
\end{abstract}

Tujuan Penelitian: Untuk mengetahui efektivitas salep ekstrak herba Pegagan (Centella asiatica (L.) Urban) terhadap penyembuhan luka bedah pada tikus putih jantan dan untuk mengetahui konsentrasi salep ekstrak herba Pegagan (Centella asiatica (L.) Urban) yang paling efektif terhadap penyembuhan luka bedah pada tikus putih jantan.

Metode: Metode yang digunakan adalah penelitian eksperimental. Hewan percobaan dibagi dalam 5 kelompok yaitu kelompok X1 merupakan kelompok uji dengan ekstrak herba Pegagan 2,5\%, kelompok X2 merupakan kelompok uji dengan ekstrak herba Pegagan 5\%, kelompok X3 merupakan kelompok uji dengan ekstrak herba Pegagan 10\%, kelompok K(+) merupakan kelompok uji dengan kontrol positif, dan kelompok K(-) merupakan kelompok uji dengan kontrol negatif.

Hasil: Hasil penelitian menunjukkan bahwa salep ekstrak Pegagan dengan konsentrasi 5\% dan $10 \%$ dapat menyembuhkan luka lebih baik dibandingkan dengan kontrol positif. Sedangkan salep ekstrak Pegagan dengan konsentrasi 2,5\% tidak mempunyai perbedaaan yang signifikan dibandingkan dengan kontrol positif (povidone iodine).

Simpulan: Pemberian salep ekstrak herba Pegagan (Centella asiatica (L.) Urban) dengan konsentrasi $2,5 \%$, 5\%, dan $10 \%$ efektif terhadap penyembuhan luka bedah pada tikus putih jantan.

Kata kunci: salep, ekstrak herba Pegagan, luka bedah

\begin{abstract}
Background: Pegagan (Centella asiatica (L.) Urban) has been studied that has good wound healing activity in surgical wound with stimulating collagen synthesis, increasing collagen secretion, stimulating fibroblast proliferation, antibacterial activity and antioxidants.

Objective: To determine the effectiveness of Pegagan herb extract (Centella asiatica (L.) Urban) in healing of surgical wound in male white rat and to determine the concentration of Pegagan herb extract (Centella asiatica (L.) Urban) which is most effective against wound healing surgery in male white rat.

Method: The method used experimental study. The experimental animals were divided into 5 groups, which are group X1 was the test group with Pegagan herb extract concentration of 2,5\%, group X2 was the test group with Pegagan herb extract concentration of 5\%, group X3 was the test group with Pegagan herb extract concentration of $10 \%$, group $K(+)$ was the test group with positive control, and group $K(-)$ was the test group with negative control.

Results: The results showed that the ointment of Pegagan extract with concentrations of 5\% and $10 \%$ could heal the wound better than the positive control. Oinment of Pegagan extract with concentration of $2,5 \%$ had not significant difference compared with positive control (povidone iodine).

Conclusion: Administration of oinment of Pegagan herb extract (Centella asiatica (L.) Urban) with concentration of $2.5 \%, 5 \%$, and $10 \%$ were effective in healing of surgical wound in male white rat.
\end{abstract}

Keywords: Ointment, pegagan herb extract, surgical wound 


\section{PENDAHULUAN}

Pegagan (Centella asiatica (L.) Urban) merupakan tanaman yang tumbuh di Indonesia dan digunakan masyarakat sebagai pengobatan tradisional, contohnya adalah sebagai pengobatan luka. ${ }^{1}$ Suatu luka jika tidak segera ditangani dengan baik maka akan dapat menyebabkan terjadinya infeksi. Beberapa dampak dan efek dari luka yang dapat terjadi yaitu hilangnya sebagian atau bahkan seluruh fungsi jaringan dan organ yang mengalami luka, perdarahan, gangguan hematologi, timbulnya beberapa respon saraf simpatis, dan kemungkinan terjadinya kontaminasi lebih kronis yang dapat mengakibatkan kematian dari beberapa sel-sel penting. ${ }^{2}$

Pegagan (Centella asiatica (L.) Urban) telah diteliti mempunyai aktivitas terhadap penyembuhan luka yang baik. Aktivitas tersebut terjadi melalui beberapa mekanisme seperti menstimulasi sintesis kolagen dan meningkatkan sekresi kolagen ${ }^{3}$, merangsang proliferasi fibroblast ${ }^{4}$, dan aktivitas antiulcer ${ }^{5}$. Selain itu Pegagan juga mempunyai aktivitas antibakteri dan antioksidan. ${ }^{6}$

Aktivitas farmakologi Pegagan disebabkan oleh beberapa senyawa termasuk asiatikosida, asam asiatat dan asam madekasat. Ekstrak herba Pegagan dan khususnya kandungan utamanya yang berupa triterpen yaitu asiatikosida yang mempunyai nilai terapeutik untuk pengobatan hipertropi bekas luka dan keloid. Asiatikosida dilaporkan mampu menurunkan fibrosis pada luka sehingga mencegah pembentukan bekas luka baru. Mekanisme aksi tersebut diperkirakan melalui dua arah yaitu dengan meningkatkan sintesis kolagen dan asam mukopolisarida, serta dengan menghambat fase inflamasi hipertropi dan keloid. ${ }^{7}$

Berdasarkan latar belakang tersebut, penulis tertarik untuk melakukan penelitian dengan judul "Uji Efektifitas Salep Ekstrak Herba Pegagan (Centella asiatica (L.) Urban) Terhadap Luka Bedah Pada Tikus" karena dalam hal ini belum ada penelitian tentang ekstrak herba pegagan dengan bentuk sediaan salep untuk luka bedah pada tikus.

\section{METODE PENELITIAN}

Jenis penelitian ini adalah penelitian eksperimen dengan rancangan penelitian adalah rancangan acak lengkap (RAL). Penelitian eksperimen adalah suatu cara untuk mencari hubungan sebab akibat (hubungan kausal) antara dua faktor yang sengaja ditimbulkan oleh peneliti dengan mengeliminasi atau mengurangi atau menyisihkan faktor-faktor lain yang mengganggu. ${ }^{8}$

Populasi pada penelitian ini adalah tanaman Pegagan (Centela asiatica (L.) Urban) dan tikus putih (Rattus norvegicus). Herba Pegagan diperoleh dari Kuningan, Jawa Barat. Sedangkan hewan uji yang digunakan pada penelitian adalah tikus putih (Rattus norvegicus) jantan, galur Wistar dengan usia 2-3 bulan berat badan kurang 150-200 gr.

Herba Pegagan (Centella asiatica (L.) Urban) yang akan digunakan harus dipilih yang sesuai dengan kriteria yaitu daun tidak rusak, tidak menguning, dan tidak busuk. Herba Pegagan dicuci sampai bersih dengan air mengalir lalu diangin-anginkan hingga kering. Pembuatan ekstrak herba Pegagan dilakukan dengan cara maserasi menggunakan etanol 70\%.

Formulasi salep yang digunakan yaitu nipagin, lanolin anhidrat, dan vaselin album berdasarkan Formularium Nasional edisi II. Formulasi salep ekstrak herba Pegagan dalam penelitian ini dapat dilihat pada Tabel 1.

Tabel 1. Formulasi salep ekstrak herba Pegagan

\begin{tabular}{lccc}
\hline \multicolumn{1}{c}{ KOMPOSISI } & X1 & X2 & X3 \\
\hline Ekstrak Pegagan & $2,5 \%$ & $5 \%$ & $10 \%$ \\
Nipagin & $0,1 \%$ & $0,1 \%$ & $0,1 \%$ \\
Lanolin anhidrat & $5 \%$ & $5 \%$ & $5 \%$ \\
Vaselin album & Sampai 50 & Sampai 50 & Sampai 50 \\
\hline
\end{tabular}

Uji efektifitas salep ekstrak pegagan

dalam penyembuhan luka bedah ini 
dilakukan pada tikus yang dibagi ke dalam 5 kelompok yaitu kontrol negatif $\mathrm{K}(-)$, kontrol positif $\mathrm{K}(+)$ dan kelompok uji (X1, $\mathrm{X} 2$, dan X3). Masing-masing kelompok terdiri dari 4 ekor tikus. Perhitungan ini berdasarkan pada rumus Federer 9 :

$(\mathrm{t}-1)(\mathrm{n}-1) \geq 15$

Keterangan: $(5-1)(n-1) \geq 15 \quad t=$ jumlah kelompok

$4 \mathrm{n}-4 \geq 15 \quad \mathrm{n}=$ banyak sampel

$4 \mathrm{n} \geq 19$

$\mathrm{n} \geq 4,75 \approx 4$

Perlakuan selengkapnya terhadap hewan uji dapat dapat dilihat pada Tabel 2 .

Tabel 2. Pembagian Kelompok dan Perlakuan

\begin{tabular}{|c|c|c|}
\hline KELOMPOK & $\begin{array}{l}\text { JUMLAH TIKUS } \\
\text { (ekor) }\end{array}$ & PERLAKUAN \\
\hline $\begin{array}{c}\mathrm{K}(-) \\
\text { (Kontrol negatif) }\end{array}$ & 4 & $\begin{array}{l}\text { tikus dibuat luka, diberi basis salep, dan ditutup } \\
\text { dengan kain kassa }\end{array}$ \\
\hline $\begin{array}{c}\mathrm{K}(+) \\
\text { (Kontrol positif) }\end{array}$ & 4 & $\begin{array}{l}\text { tikus dibuat luka, diberi salepiodine povidone } \\
\text { dua kali sehari, dan ditutup dengan kain kassa }\end{array}$ \\
\hline $\begin{array}{c}X 1 \\
(2,5 \%)\end{array}$ & 4 & $\begin{array}{l}\text { tikus dibuat luka, dan diberi salep extrak } \\
\text { Pegagan2,5\% dua kali sehari, luka ditutup } \\
\text { dengan kain kassa }\end{array}$ \\
\hline $\begin{array}{c}\mathrm{X} 2 \\
(5 \%)\end{array}$ & 4 & $\begin{array}{l}\text { tikus dibuat luka, dan diberi salep extrak } \\
\text { Pegagan } 5 \% \text { dua kali sehari, luka ditutup } \\
\text { dengan kain kassa }\end{array}$ \\
\hline $\begin{array}{c}\mathrm{X} 3 \\
(10 \%)\end{array}$ & 4 & $\begin{array}{l}\text { tikus dibuat luka, dan diberi salep extrak } \\
\text { Pegagan } 10 \% \text { dua kali sehari, luka ditutup } \\
\text { dengan kain kassa }\end{array}$ \\
\hline
\end{tabular}

Pembuatan luka dilakukan menurut metode Morton $^{10}$ yaitu sebagai berikut: Tikus dicukur rambutnya di daerah punggung bagian atas (dilakukan sehari sebelum pembuatan luka). Pada saat akan di buat luka, tikus di anastesi terlebih dahulu menggunakan dietil eter. Daerah punggung tikus bagian atas dan sekitarnya dibersihkan dengan alkohol 70\%. Setelah itu dibuat luka berbentuk lingkaran dengan diameter $2 \mathrm{~cm}$, dengan cara mengangkat kulit dengan pinset dan gunting kulit menggunakan gunting bedah hingga bagian subkutis hingga bagian dermis beserta jaringan ikat.

Pengamatan penyembuhan luka persentase penyembuhan luka. Luas luka diamati dengan cara mengukur rata-rata diameter luka pada arah vertikal, horizontal, dan kedua diagonal. Cara penilaian luas penyembuhan luka yaitu : $\pi$ $\mathrm{xr}^{2}=\pi \mathrm{x}\left(\frac{1}{2} \mathrm{~d}\right)^{2}=\frac{1}{4} \pi \mathrm{d}^{2}=0,7854 \mathrm{~d}^{2}$, sedangkan untuk persentase penyembuhan luka adalah $: \underline{\mathrm{d}}_{0}{ }^{2}-\mathrm{d}_{\underline{n}}{ }^{2} \times 100 \%$

$\mathrm{d}_{0}{ }^{2}$

keterangan: $\mathrm{d}=$ diameter rata rata

$\mathrm{d}_{0}=$ diameter luka pada saat

tikus dibedah (hari ke-0)

$\mathrm{d}_{\mathrm{n}}=$ diameter luka pada hari ke

- $\mathrm{n}$ dilakukan pengamatan. tersebut dilihat dari luas luka atau

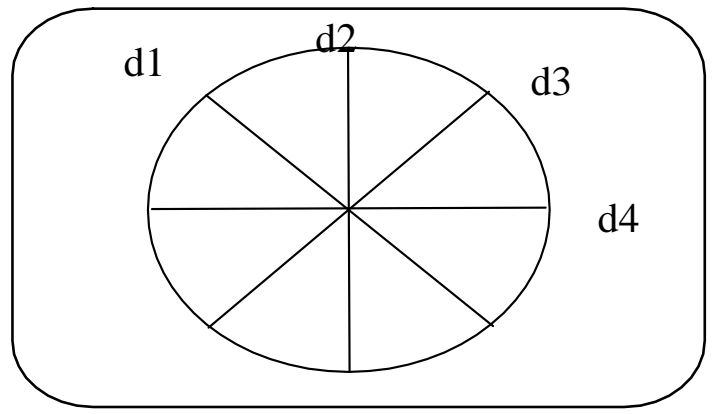

Gambar 1. Pengukuran Arah Diameter Luka 
Pengamatan persentase penyembuhan luka dilakukan 24 jam setelah pembuatan luka dan bahan uji mulai diberikan (hari ke-1) sampai hari ke7. Di samping pengukuran luas luka, pengamatan penyembuhan luka diamati berdasarkan parameter warna inflamasi pada luka tikus putih jantan dari hari ke-0 (setelah pembuatan luka dan pemberian bahan uji), yaitu: +++ untuk Merah sekali, + + untuk Merah, + untuk Agak merah, dan untuk kering.

Setelah hasil percobaan didapatkan kemudian dianalisis dengan menggunakan
Anava satu arah, analisa dilanjutkan dengan uji $t$ untuk mencari konsentrasi salep ekstrak herba Pegagan yang terbaik.11

\section{HASIL PENELITIAN}

Dari hasil determinasi tanaman menunjukkan bahwa bahan uji simplisia yang digunakan dalam penelitian ini adalah benar herba Pegagan (Centella asiatica (L.) Urban) dengan nilai persentase rendemen ekstrak sebesar 18\%. Hasil pengamatan luas penyembuhan luka bedah dapat dilihat pada Tabel 3.

Keterangan:

\section{Tabel 3. Hasil Pengamatan Luas Penyembuhan Luka Bedah}

X1 : Kelompok uji 1 (salep ekstrak herba Pegagan 2,5\%)

X2 : Kelompok uji 2 (salep ekstrak herba Pegagan 5\%)

X3 : Kelompok uji 3 (salep ekstrak herba Pegagan 10\%)

$\mathrm{K}(+) \quad$ : Kontrol positif (salep iodine povidone)

$\mathrm{K}(-) \quad$ : Kontrol negatif (basis salep)

Perlakuan Tikus

Luas Luka Hari $\mathrm{Ke}-\left(\mathrm{cm}^{2}\right)$

\begin{tabular}{cccccccccc} 
& & 0 & 1 & 2 & 3 & 4 & 5 & 6 & 7 \\
\hline & 1 & 0,99 & 0,90 & 0,79 & 0,71 & 0,66 & 0,61 & 0,50 & 0,41 \\
X1 & 2 & 1,43 & 1,23 & 1,04 & 0,95 & 0,92 & 0,87 & 0,71 & 0,68 \\
& 3 & 1,04 & 0,95 & 0,80 & 0,66 & 0,64 & 0,57 & 0,48 & 0,44 \\
& 4 & 0,95 & 0,87 & 0,80 & 0,66 & 0,64 & 0,57 & 0,47 & 0,44 \\
& Rata-Rata & 1,09 & 0,98 & 0,85 & 0,74 & 0,71 & 0,65 & 0,53 & 0,49 \\
& 1 & 1,43 & 1,33 & 1,23 & 0,95 & 0,85 & 0,79 & 0,64 & 0,65 \\
X2 & 2 & 1,33 & 1,15 & 1,00 & 0,80 & 0,71 & 0,64 & 0,52 & 0,50 \\
& 3 & 1,17 & 1,04 & 0,82 & 0,64 & 0,57 & 0,50 & 0,38 & 0,32 \\
& 4 & 1,54 & 1,33 & 1,13 & 1,11 & 0,95 & 0,87 & 0,71 & 0,64 \\
& Rata-Rata & 1,36 & 1,21 & 1,04 & 0,87 & 0,76 & 0,69 & 0,55 & 0,52 \\
& 1 & 1,41 & 1,31 & 1,13 & 0,95 & 0,79 & 0,65 & 0,57 & 0,57 \\
X3 & 2 & 1,33 & 1,13 & 0,95 & 0,72 & 0,61 & 0,54 & 0,44 & 0,35 \\
& 3 & 1,13 & 0,99 & 0,79 & 0,79 & 0,64 & 0,53 & 0,57 & 0,52 \\
& 4 & 1,04 & 0,87 & 0,64 & 0,50 & 0,44 & 0,38 & 0,33 & 0,28 \\
& Rata-Rata & 1,22 & 1,07 & 0,87 & 0,73 & 0,61 & 0,52 & 0,47 & 0,42 \\
& 1 & 1,23 & 1,11 & 0,95 & 0,80 & 0,71 & 0,64 & 0,58 & 0,52 \\
K & 2 & 1,33 & 1,23 & 1,11 & 0,95 & 0,82 & 0,71 & 0,64 & 0,57 \\
$(+)$ & 3 & 1,61 & 1,43 & 1,23 & 1,04 & 0,94 & 0,88 & 0,79 & 0,71 \\
& 4 & 1,54 & 1,33 & 1,13 & 0,95 & 0,82 & 0,72 & 0,68 & 0,62 \\
& Rata-Rata & 1,42 & 1,27 & 1,10 & 0,93 & 0,82 & 0,74 & 0,67 & 0,60 \\
& 1 & 1,13 & 1,06 & 0,99 & 0,87 & 0,79 & 0,69 & 0,64 & 0,57 \\
K & 2 & 1,04 & 0,99 & 0,87 & 0,79 & 0,72 & 0,64 & 0,58 & 0,53 \\
$(-)$ & 3 & 1,65 & 1,54 & 1,43 & 1,43 & 1,25 & 1,15 & 1,06 & 0,99 \\
& 4 & 1,54 & 1,43 & 1,33 & 1,21 & 1,04 & 0,93 & 0,83 & 0,79 \\
& Rata-Rata & 1,33 & 1,24 & 1,14 & 1,06 & 0,94 & 0,84 & 0,77 & 0,71 \\
\hline
\end{tabular}

Hasil pengamatan persentase penyembuhan luka bedah dapat dilihat pada Tabel 4 . 
Journal of Holistic and Health Sciences

Vol.1, No.2, Juli-Des e m b e r 2017 |98

\section{Tabel 4. Hasil Pengamatan Persentase Penyembuhan Luka Bedah}

Keterangan:

X1 : Kelompok uji 1 (salep ekstrak herba Pegagan 2,5\%)

X2 : Kelompok uji 2 (salep ekstrak herba Pegagan 5\%)

X3 : Kelompok uji 3 (salep ekstrak herba Pegagan 10\%)

$\mathrm{K}(+) \quad$ : Kontrol positif (salep iodine povidone)

$\mathrm{K}(-) \quad$ : Kontrol negatif (basis salep)

\begin{tabular}{|c|c|c|c|c|c|c|c|c|}
\hline \multirow{2}{*}{\multicolumn{2}{|c|}{ Perlakuan Tikus }} & \multicolumn{7}{|c|}{ Persentase Penyembuhan Luka Hari Ke - (\%) } \\
\hline & & 1 & 2 & 3 & 4 & 5 & 6 & 7 \\
\hline \multirow{6}{*}{$\mathrm{X} 1$} & 1 & 8,73 & 20,28 & 28,05 & 32,53 & 38,27 & 48,98 & 58,67 \\
\hline & 2 & 14,27 & 27,43 & 33,61 & 36,00 & 39,51 & 50,48 & 52,54 \\
\hline & 3 & 8,51 & 22,87 & 36,00 & 38,75 & 45,37 & 54,00 & 57,47 \\
\hline & 4 & 8,88 & 15,69 & 30,05 & 33,06 & 40,29 & 51,00 & 53,51 \\
\hline & Rata-Rata & 10,31 & 21,95 & 32,08 & 35,18 & 40,85 & 51,12 & 55,46 \\
\hline & 1 & 7,27 & 14,27 & 33,61 & 40,65 & 45,13 & 55,56 & 54,56 \\
\hline \multirow{3}{*}{$\mathrm{X} 2$} & 2 & 13,37 & 24,44 & 39,64 & 46,60 & 52,07 & 61,18 & 62,13 \\
\hline & 3 & 11,15 & 30,10 & 45,58 & 51,46 & 57,00 & 67,08 & 72,48 \\
\hline & 4 & 13,78 & 26,53 & 27,75 & 38,27 & 43,75 & 53,95 & 58,67 \\
\hline \multirow{7}{*}{ X3 } & Rata-Rata & 11,42 & 23,81 & 36,48 & 44,11 & 49,37 & 59,35 & 61,97 \\
\hline & 1 & 7,32 & 19,80 & 32,61 & 44,31 & 53,88 & 59,76 & 59,76 \\
\hline & 2 & 14,79 & 28,40 & 45,47 & 54,18 & 59,24 & 66,72 & 73,44 \\
\hline & 3 & 12,89 & 30,56 & 30,56 & 43,75 & 53,31 & 49,83 & 54,44 \\
\hline & 4 & 16,64 & 38,75 & 51,61 & 57,47 & 62,95 & 68,05 & 72,78 \\
\hline & Rata-Rata & 12,79 & 29,16 & 40,16 & 49,96 & 57,32 & 61,41 & 65,52 \\
\hline & 1 & 9,37 & 22,56 & 34,71 & 42,24 & 48,16 & 52,67 & 58,01 \\
\hline \multirow{3}{*}{$\begin{array}{c}\mathrm{K} \\
(+)\end{array}$} & 2 & 7,54 & 16,21 & 28,40 & 38,44 & 46,60 & 52,07 & 57,25 \\
\hline & 3 & 10,88 & 23,59 & 35,33 & 41,37 & 45,05 & 51,10 & 55,87 \\
\hline & 4 & 13,78 & 26,53 & 38,27 & 46,92 & 52,98 & 55,87 & 59,59 \\
\hline \multirow{6}{*}{$\begin{array}{c}\mathrm{K}(- \\
)\end{array}$} & Rata-Rata & 10,49 & 22,38 & 34,32 & 42,35 & 48,26 & 52,96 & 57,68 \\
\hline & 1 & 6,56 & 12,89 & 23,44 & 30,56 & 38,64 & 43,75 & 49,83 \\
\hline & 2 & 5,15 & 16,64 & 24,39 & 30,31 & 38,75 & 44,08 & 49,16 \\
\hline & 3 & 6,78 & 13,32 & 13,32 & 24,49 & 30,36 & 36,00 & 40,34 \\
\hline & 4 & 7,02 & 13,78 & 21,55 & 32,53 & 39,38 & 45,87 & 48,98 \\
\hline & Rata-Rata & 6,43 & 14,08 & 20,38 & 29,38 & 36,61 & 42,30 & 46,88 \\
\hline
\end{tabular}

Berikut adalah grafik persentase penyembuhan luka bedah :

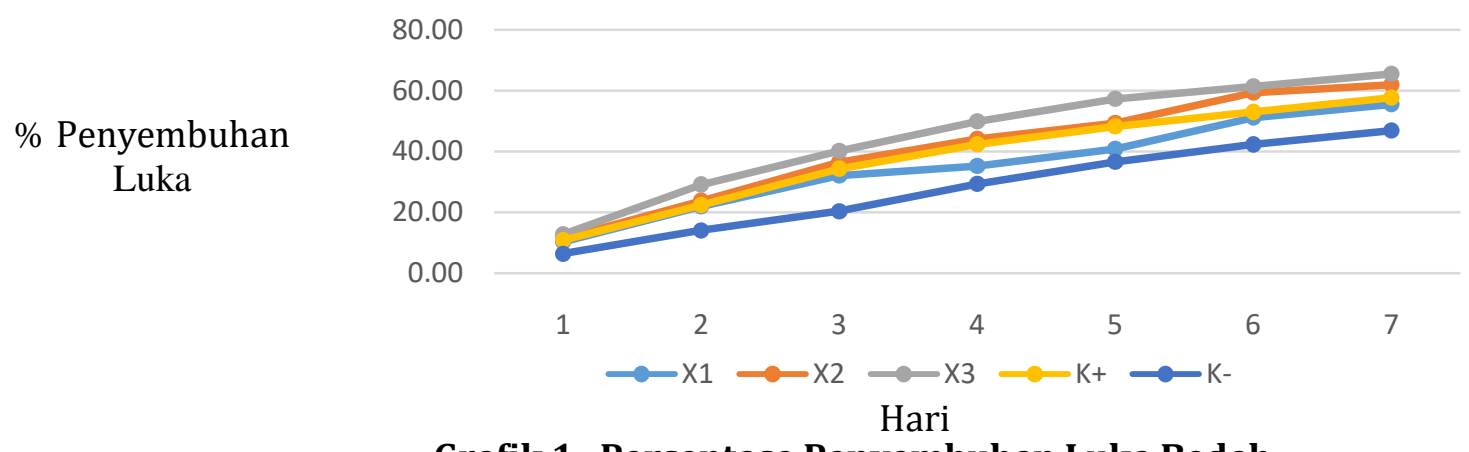

Grafik 1. Persentase Penyembuhan Luka Bedah 
Hasil analisis data dengan taraf nyata $(\alpha=5 \%)$ didapatkan $\mathrm{F}$ tabel $=2,45$. Karena $\mathrm{F}$ hitung $=30,88$ yaitu lebih besar dari $\mathrm{F}$ tabel $=2,45$ maka $\mathrm{H}_{0}$ ditolak. Ini berarti bahwa kontrol uji memberi pengaruh yang signifikan terhadap penyembuhan luka bedah pada tikus. Kemudian dilanjutkan dengan uji t. Uji t yang pertama adalah uji $t$ untuk salep ekstrak herba pegagan $2,5 \%$ dengan Kontrol (+) dan didapatkan $\mathrm{t}$ hitung $\leq \mathrm{t}$ tabel yaitu $-2,781 \leq 2,179$ sehingga Ho diterima dan $\mathrm{H}_{1}$ ditolak

Selanjutnya Uji t Salep Ekstrak Herba Pegagan 5\% dengan Kontrol (+) dan didapatkan hasil $\mathrm{t}$ hitung $\geq \mathrm{t}$ tabel yaitu $3,280 \geq 2,179$ sehingga Ho ditolak dan $\mathrm{H}_{1}$ diterima. Kemudian Uji t Salep Ekstrak Herba Pegagan 10\% dengan Kontrol (+) didapatkan hasil $\mathrm{t}$ hitung $\geq \mathrm{t}$ tabel yaitu 7,548 $\geq 2,179$ sehingga Ho ditolak dan $\mathrm{H}_{1}$ diterima.

\section{PEMBAHASAN}

Berdasarkan analisis statistik uji ANAVA satu arah terjadi perbedaan signifikan antara X1, X2, X3, kontrol positif, dan kontrol negatif. Uji statistik ini menganalisis uji efektivitas kesembuhan dengan membandingkan nilai $\mathrm{F}$ hitung dengan $\mathrm{F}$ tabel. Jika diambil taraf nyata $5 \%$, maka dari Daftar D, didapat $\mathrm{F}$ tabel $=2,45$. Karena $\mathrm{F}$ hitung $=30,88$ lebih besar dari $\mathrm{F}$ tabel $=2,45$ maka hipotesis nol (Ho) ditolak. Hal ini menunjukkan bahwa pemberian povidon iodine, salep ekstrak herba Pegagan mempunyai efek terhadap penyembuhan luka. Povidon iodine berpengaruh terhadap penyembuhan luka dikarenakan povidon iodine merupakan suatu antiseptik yang dapat membunuh kuman gram positif dan gram negatif. Salep ekstrak herba Pegagan memberikan pengaruh penyembuhan luka melalui berbagai mekanisme yaitu menstimulasi sintesis kolagen dan meningkatkan sekresi kolagen $^{3}$, merangsang proliferasi fibroblast ${ }^{4}$, dan aktivitas antiulcer ${ }^{5}$. Selain itu, Pegagan juga mempunyai aktivitas antibakteri dan antioksidan. ${ }^{6}$

Berdasarkan pengamatan makroskopik, terbentuknya keropeng terjadi mulai hari ke-3 pada kelompok X1, X2, X3, dan K (+). Pembentukan keropeng menunjukkan proses penyembuhan luka memasuki fase proliferasi tahap awal. Sedangkan pada kelompok K (-) belum terjadi pembentukan keropeng yang menandakan bahwa proses penyembuhan luka berjalan lambat.

Berdasarkan grafik persentase penyembuhan luka terlihat bahwa rata-rata persentase penyembuhan luka X1, X2, X3, dan kontrol positif lebih tinggi dibandingkan dengan kontrol negatif. Persentase penyembuhan terbesar terjadi pada kelompok tikus yang diberikan salep ekstrak herba Pegagan 10\%, sedangkan persentase penyembuhan luka terkecil terjadi pada kelompok kontrol negatif dengan pemberian basis salep.

Urutan penyembuhan luka mulai dari yang terbesar adalah salep ektrak herba Pegagan 10\%, salep ekstrak herba Pegagan 5\%, kontrol positif, salep ekstrak herba Pegagan 2,5\%, dan kontrol negatif. Persentase penyembuhan luka terbesar dicapai oleh kelompok tikus yang diberikan salep ekstrak herba Pegagan 10\%, diduga karena Pegagan mengandung senyawa asiatikosida, madekakosida, asam asiatat, dan asam madekasat. Senyawa ini yang berperan terhadap penyembuhan luka melalui berbagai mekanisme. Pertama, meningkatkan proliferasi fibroblast. Fibroblast mempunyai peran penting dalam penyembuhan luka karena kemampuannya dalam memproduksi substansi dasar pembentuk serat kolagen. ${ }^{3}$ Kedua, menstimulasi sintesis kolagen dan meningkatkan sekresi kolagen. ${ }^{4}$

Analisis uji $t$ bertujuan untuk mengevaluasi ketiga kontrol uji dengan kontrol positif, jika - $\mathrm{t}$ tabel $\leq \mathrm{t}$ hitung $\leq+\mathrm{t}$ tabel maka Ho diterima dan $\mathrm{H}_{1}$ ditolak. Jika Ho diterima berarti tidak terdapat perbedaan efektivitas yang signifikan pada salep ekstrak herba Pegagan dengan kontrol positif terhadap penyembuhan luka bedah pada tikus putih jantan. Berdasarkan analisis uji t, X1 dengan kontrol positif tidak menunjukkan perbedaan yang signifikan secara statistik karena nilai $\mathrm{t}$ tabel lebih besar dari pada $t$ hitung. Hal ini dapat terjadi di duga karena kandungan senyawa berkhasiat pada salep ekstrak herba Pegagan 2,5\% sehingga tidak mencukupi 
kebutuhan metabolik tikus untuk memberikan hasil yang lebih baik dan berbeda signifikan dengan kontrol positif yang diberi povidone iodine.

Namun untuk analisis uji t pada $\mathrm{X} 2$ dan X3 dengan kontrol positif menunjukan perbedaan yang signifikan secara statistik karena nilai $\mathrm{t}$ tabel lebih kecil dari pada $\mathrm{t}$ hitung. Hal ini dapat dilihat dari hasil pengamatan bahwa X2 dan X3 memiliki persentase penyembuhan luka yang lebih baik dibandingkan kontrol positif.

\section{SIMPULAN}

Dari hasil penelitian yang telah dilakukan dapat diambil kesimpulan bahwa pemberian salep ekstrak herba Pegagan (Centella asiatica (L.) Urban) dengan konsentrasi 2,5\%, 5\%, dan 10\% efektif terhadap penyembuhan luka bedah pada tikus putih jantan.Salep ekstrak herba Pegagan (Centella asiatica (L.) Urban) dengan konsentrasi 5\% dan 10\% dapat menyembuhkan luka lebih baik dibandingkan dengan kontrol positif pada tikus putih jantan. Sedangkan salep ekstrak herba Pegagan (Centella asiatica (L.) Urban) dengan konsentasi 2,5\% tidak mempunyai perbedaan yang signifikan dibandingkan dengan kontrol positif (povidone iodine).

\section{DAFTAR PUSTAKA}

1. Badan Pengawas Obat dan Makanan Republik Indonesia. Taksonomi Koleksi Tanaman Obat Kebun Tanaman Obat Citeureup. Jakarta: BPOM RI; 2008.

2. Lans. C. Comparison of plants used for skin and aeruginosa. J. Microbial Immunol Infect: Stomach problems in Trinidad and Tobago. Asian ethnomedicine. Journal of Ethnobiology and Ethnomedicine. 2007; 3; 42: 364370.

3. Zheng, Cheng Jian. Chemical Components of Centella asiatica and Their Bioactivities. Journal of Chinese Integrative Medicine. 2007; 3.

4. Kusumawati, Ratna. Pemberian infusa Pegagan (Centella asiatica (L.) Urban terhadap Proliferasi Sel Fibroblast pada Proses Penyembuhan Luka. Undergraduate Theses Airlangga University. Diunduh dari URL http://adln.lab.unair.ac.id. Diakses pada 5 Januari 2011.

5. Abdulla. Anti-ulcer Activity of Centella asiatica Leaf Extract Against Ethanolinduced Gastric Mucosal Injury in Rats. Journal of Medical Plants Research 4. 2010; 5.

6. Pittela et al. Antioxidant and Cytotoxic Activity of Centella asiatica (L.) Urb. International Journal of Molecular Science. 2009; 10.

7. Badan Pengawas Obat dan Makanan Republik Indonesia. Serial Data Ilmiah Terkini Tumbuhan Obat Pegagan Centella asiatica (l.) Urban. Jakarta: BPOM RI; 2010.

8. Arikunto S. Prosedur Penelitian Suatu Pendekatan Praktek. PT. Rineka Cipta; 2010.

9. Jusman, S. W., Halim, A. Oxidative Stress in Liver Tissue of Rat Induced by Chronic Systemic Hypoxia. Jurnal Makara Kesehatan. 2009; 13.

10. Black, Joyce and Hawk, Jane. Medical Surgical Nursery: Clinical Management for Positif Outcome. 8th Edition. USA: Elsevier; 2009.

11. Sujana, Prof. Dr. Design dan Analisa Eksperimen Edisi IV. Bandung: Tarsito; 2012. 